A New Needle for Suturing Purposes

To the Editor:-In THE Journal, Oct. 21, 1916, p. 1228, Dr. William C. Speidel, Seattle, describes and illustrates "a new needle for suturing purposes" which has a central eye. Such a needle has been in general use in this country and England for several years, and was described and illustrated by P. P. Cole in the Lancet, London, Sept. 5, 1914, and is also described and illustrated in "Practical Medical Series," 1915, Volume II, p. 34 .

Woodson H. Taulbee, M.D., Maysville, Ky.

\section{Queries and Minor Notes}

ANonymous Communications and queries on postal cards will not he noticed. Every letter must contain the writer's name and adilress, but these will be omitted, on request:

\section{WHAT IS PYORRHEA?}

To the Editor:-Kindly advise me whether a physician and surgeon, regularly licensed under the Illinois law and thereby empowered to practice medicine and surgery in all their branches, requires a license as a dentist before he may treat pyorrhea alveolaris.

William A. Lurie, M.D., Chicago.

ANswer.-The Illinois medical practice act defines the practice of medicine as treating or professing to treat, operating on or prescribing for any physical ailment or any phrsical injury to or deformity of another. The Illinois dental law defines dentistry as treating or professing to treat any of the diseases or lesions of the human teeth or jaws, or extracting teeth, or preparing or filling cavities in human teeth, or correcting the malposition of teeth, or supplying artificial teeth as substitutes for natural teeth. Where is the dividing line between medicine and dentistry? In 1899, the Rhode Island supreme court (State v. Beck, 21 R. I. 288, 43 At1. 366) held that a legally qualified physician could practice dentistry. The court said:

Dentistry is now a well recognized branch of surgery. A dentist is a dental surgeon. He performs surgical operations on the teeth and jaw and as incidental thereto upon the flesh connected therewith. The sphere of operations, then, is included in the larger one of the physician and surgeon. A fair and reasonable construction of the two statutes taken together, therefore, comes to this, that the General Assembly . . . intended to except physicians and surgeons from the restrictions imposed on other persons regarding the practice dentistry. . . It has always been the custom in this state and probably everywhere else for physicians to treat ailing teeth, to extract teeth and to perform various other professional services which teclnically come under the purview of dentistry. . . To now prohilit them from thus treating their patients would be . . - interference with their proper and legitimate functions.

In 1909, the Minnesota supreme court held (State v. Tavlor 106 Minn. 218, 118 N. W. 1012) that a person licensed to practice medicine and surgery camnot by virtue thereof practice dentistry without securing a license as a dentist. In this case, the defendant extracted teeth, took impressions in wax of the mouth and cavities, secured artificial teeth from dental laboratories and delivered them to patients. The court held that in the absence of any legislation to the contrary, a license to practice medicine and surgery would include dentistry, but that for reasons of public policy, the legislature had made a separate profession of dentistry. The acts of the defendant came clearly within the definition of dentistry. The legislature evidently intended to restrict the practice of the physician and surgeon and to require him, if he desires to practice dentistry, to obtain a license from the state board of dental examiners.

The question still remains whether pyorrhea is a purely local disease, involving only the teeth and gums, or whether it is a local evidence of a general and constitutional condition. Even if it is conceded that it is a purely local condition, is it a disease of the teeth or of the bone? If it is regarded as a disease of the bone, would the board of dental examiners take the position that all diseases of the jaw bone come exclusively within the realm of dentistry? If so, then the surgeon who treats a gunshot wound or a fracture of the jaw or who removes an osteosarcoma, or the rhinologist who drains an infected superior maxillary sinus, must first secure a license to practice dentistry. If the dental law forbids the physician to use local treatment for pyorrhea, does not the medical law prohibit the dentist from using general treat- ment for the same condition? Must the patient with pyorrhea have a dentist on one side for local treatment and a physician on the other to administer general treatment? This reduces the question to an absurdity. The right of the dentist under the Illinois statute to the, extracting of teeth, the filling of cavities, the correction of malpositions and the supplying of artificial teeth will probably not be questioned. The controversy will center around that part of the statutory definition of dentistry which includes "treating any of the cliseases or lesions of luman teeth or jaus." If this is interpreted literally by the courts, it can only lead to confusion.

MENTAL DISTURBANCES DEE TO WAR

To the Editor: Please give a list of publications dealing with special or new corms of nuental diseases arising from conditions at the front, or indirectiy cansed by economic war conditions in the different con tries affected.

Axswer.-The following is a list of references on this subject:

Claude, Dide, and Lejonne: War Psychoses, Paris mid., Sept. $2,1916$.

Psyclic Disturbances Incident to the War, Berlin Letter, Tus. Journal., April 29, 1916, p. 1398.

Chavigny, P.: Psychiatry in the Active Army, Paris míd., Jan, 1 1916; abstr., Tine Journal, Feb. 12, 1916, p. 538

Soukhanoff, S. A.: War Psychoses, Russk. Prach., 1915, xiv, No. 34 Weygandt, W.: Psychiatry in War, Minchen, med. Wchnschr., Sept. 14, 1915; Mental Disease in War, ibid., Oct. 27, 1914.

Wittermann, E.: Psychiatry on the Firing Line, Mïnchen. med. Wh chllschr., Aug. 24, 1915.

Emslie, I.: War and Psychiatry, Edinburgh Med. Jowr., May, 1915.

Oppenheim, H.: War Neurology, Berl. klin. Wchnschr., Nov. 30. 1914; abstr., ThE Journal, Jan, 16, 1915, p. 280.

- Bonhoeffer, K.: Psychiatry and War, Deutsch. med. Wchnschr., Sept 24, $191+$; abstr., Tue Journal, Nov. 7, 1914, p. 1703 .

\section{CHYLURIA AND FIIARIASIS}

To the Fiditor:-Please give me information as to whether the $1 \mathrm{ym}$. phatic disease with chylous urine, attacks of pain in the muscles and fever ilue to filaria, which have been found in the blood taken at night in the case of a Cuban, is curable; also give the method of procedure with drugs to be used. I have heard that thymol is good for this pur. pose; others say that there is no drug of service-that change of climate is the only thing.

Fioyd Bonesteel Ennist, M.D., New York.

Answer.-The treatment of chyluria, according to Manson and others, is to send the patient to bed, elevate the pelvis, restrict the amount of food and fluid-especially fatty foodgentle purgation, and absolute rest. A day or two of this kind of treatment will probably be followed by temporary or prolonged cessation of the chyluria. Drug treatment of filariasis is uniformly disappointing. The drugs which have been recommended for the treatment of this disease are gallic acid in large doses, benzoic acid in large doses, glycerin, the tincture of ferric chlorid, decoction of mangrove bark, chromic acid, quinin, sodium salicylate, ichthyol, and Nigella sativa. It is not probable that these substances have any influence in stopping the lymphorrhagia, nor is it likely that thymol or methylene blue have any effect either on the filaria or on the disease it causes. Both drugs have been tried, but the results have not been satisfactory. It should not be forgotten that a filarious patient, for the protection of others, should sleep under a net, the varieties of mosquitoes capable of acting as intermediate hosts being numerous.

\section{IODIN AS A DOUCHE FOR TEETH}

To the Editor:-I have found marked benefit from the application of tincture of iodin, 5 per cent. solution, to the gums around the roots of the teeth. Do you know of any good substitute, as the iodin dis. colors the teeth? Please do not publish my name.

Answer.-Black, in his work on "Dental Pathology," recommends that the patient be taught to douche the gums twice daily with physiologic sodium chlorid solution. A rubber bulb syringe with a tolerably large nozzle is advised. This is to be held in such position that the stream will pass into and wash out the space between the edge of the gums and the teeth. In this way inflammation, which would otherwise result from accumulation of bacteria and their products, may be prevented. Black also states that more than half of all inflammations of the gums are due to slight traumatisms of various kinds, due to such causes as the lodgment of food between teeth, rough edges of fillings, crowns, etc. 